Jurnal Ekonomi Pembangunan

Volume 11, Nomor 2, Desember 2010, hlm.254-265

\title{
STIMULUS EKSPOR TERHADAP KINERJA PERUSAHAAN-PERUSAHAAN BATIK
}

\author{
Darmansyah ${ }^{1}$ dan Daryono Soebagyo ${ }^{2}$ \\ ${ }^{1}$ Fakultas Ekonomi Universitas Bengkulu \\ Jalan Raya Kandang Limun- Bengkulu 38371 Sumatera, Indonesia \\ ${ }^{2}$ Fakultas Ekonomi Universitas Muhammadiyah Surakarta \\ Jalan A.Yani, Tromol Pos 1 Pabelan Surakarta 57102, Indonesia Telepon +62-271-717417 psw.229
}

Diterima 20 September 2010/Disetujui 5 Nopember 2010

\begin{abstract}
This study analyzes batik export performance in ex Karesidenan Surakarta. The Researcher links the export stimulus and toward export strategy and also to the impact of export stimulus, and export strategy on export performance. The purpose of this study is to explain the relationship between export stimulus and toward the export strategy. This study is also aiming at explaining about the relation of the export stimulus, and export strategy toward export performance of Batik Company. The location of this study was in Ex Karesidenan of Surakarta. The total samples of this research were 108 companies but only 104 companies which could be investigated. The significant finding of this study is that the aid of market information from domestic/local government and importer and their political stability (environmental aspect) will improve the export performance. The strong willingness of the company managers to explore the existing resources owned by the companies will support the export performance (impulse factor).
\end{abstract}

Keywords: export stimulus, export strategy, export performance

\begin{abstract}
Abstrak: Penelitian ini menganalisis pencapaian ekspor batik di Eks Karesidenan Surakarta. Peneliti mengaitkan antara stimulus ekspor dengan strategi ekspor serta melihat dampak stimulus ekspor, dan strategi ekspor terhadap pencapaian ekspor. Lokasi penelitian ini adalah kabupaten/kota di eks kresidenan Surakarta dengan sampel sebanyak 108 perusahaan dan yang bisa diolah 104.Temuan penting dalam penelitian ini adalah bahwa bantuan informasi pasar dari pemerintah domestik maupun negara importir serta kestabilan politik domestik maupun negara importir akan membantu peningkatan pencapaian ekspor. Juga keinginan yang kuat dari pimpinan perusahaan untuk selalu memanfaatkan sumber daya yang dimilikinya ke arah ekspor bisa mendorong pencapaian ekspor (impulse factor).
\end{abstract}

Kata kunci: stimulus ekspor, strategi ekspor, pencapaian ekspor

\section{PENDAHULUAN}

Industri batik merupakan salah satu dari 14 kelompok klasifikasi industri kreatif di Indonesia sebagai ciri khas bangsa Indonesia yang dikenal di mancanegara (Deperindag, 2007). Pemerintah akan terus memfasilitasi perajin batik untuk mengembangkan merek dan mendaftarkan paten. Ekspor batik Jawa Tengah tahun 2007 sebesar US\$29,3 juta atau naik 20,24 persen dibanding tahun 2006 sebesar US\$24,4 juta. Nilai tersebut merupakan 36,46 persen dari total ekspor batik Indonesia tahun 2007. Nilai ekspor 2007 tersebut, telah mengalami peningkatan sekitar 20 persen dibanding tahun 2006 yang mencapai sekitar US\$25 juta. Sedangkan, dari total nilai ekspor yang disumbangkan Jateng tersebut, 40 persen di antaranya berasal dari Solo.

Berdasarkan hasil pengumpulan data eks- 
por batik di tujuh Kota/Kabupaten di Eks Karesidenan Surakarta menurut komoditi selama tiga tahun terakhir terlihat bahwa batik dan batik garment dipisahkan dari komoditi ekspor untuk tekstil dan produk tekstil. Selama tahun 2006-2008 ekspor batik dan batik garmen mengalami fluktuasi naik turun, demikian pula dengan jumlah komoditi yang diekspor juga mengalami perubahan dari tahun ke tahun seperti yang terlihat pada Tabel 1 .

Dari Tabel 1 tampak bahwa ekspor batik dan batik garmen tahun 2006 sampai 2008 mengalami fluktuasi signifikan. Tahun 2006 sampai tahun 2007, ekspor batik dan batik garmen yang berasal dari 7 Kabupaten/Kota yang ada di Eks Karesidenan Surakarta mengalami penurunan maupun kenaikan, seperti Kabupaten Sragen, Kabupaten Wonogiri dan Kabupaten Sukoharjo mengalami penurunan jumlah ekspor, sedangkan untuk Kota Surakarta, Kabupaten Karanganyar, Kabupaten Boyolali dan Kabupaten Klaten terjadi kenaikan signifikan. Pada tahun 2007-2008 terjadi fluktuasi ekspor batik dan batik garmen dari 7 Kabupaten/Kota yang ada di Eks Karesidenan Surakarta, $5 \mathrm{Ka}$ bupaten/Kota mengalami kenaikan ekspor, dan hanya 2 Kabupaten yang mengalami penurunan, yaitu Kabupaten Karanganyar dan Kabupaten Klaten yang sebelumnya pada tahun 2006-2007 mengalami kenaikan.

Adanya pengakuan dari UNESCO, tentang batik sebagai salah satu warisan dunia, membawa semangat baru, dan memberikan efek psikologis yang baik. Berdampak terhadap pangsa penjualan menjadi meningkat, produksi tumbuh. Sungguhpun demikian, Ekspor batik Indonesia sejak lama telah menghadapi tantangan plagiasi dari negara-negara tujuan ekspor. Misalnya Cina yang dikenal dalam memplagiat produk ekspor negara lain dan memproduksi secara massal. Apalagi setelah disetujuinya penerapan perjanjian perdagangan bebas (Free Trade Area/FTA) Indonesia dengan Cina diperkirakan dapat menghancurkan industri nasional dan memunculkan PHK besar-besaran (Ketua GKBI, kompas.com). Awal tahun 2010 diberitakan sebanyak 271 perusahan iindustri tekstil dan produk tekstil (TPT) dalam negeri tutup selama tiga tahun terakir. Hal ini terjadi pasca penurunan bea masuk (BM) untuk sejumlah produk impor termasuk TPT. Asosiasi Pertekstilan Indonesia (API) memperkirakan, tren deindustrialisasi tektil ini akan terus terjadi, terlebih bila perdagangan bebas ASEAN dan Cina (ACFTA) tidak ditunda (Republika, 2010). Mengingat tantangan ekspor batik ke depan makin besar maka para pengusaha harus menyiapkan diri untuk menghadapi pasar bebas dengan sejumlah langkah.

Pada ACFTA perdagangan bebas dengan Cina adalah yang paling mengkhawatirkan lantaran produksi batik printing Cina dapat mengancam pelaku usaha kecil dan menengah (UKM) batik khususnya batik printing. Seperti yang dinyatakan secara khusus tentang produksi batik di Solo oleh Alpha (2010), batik printing Solo menguasai 60 persen hingga 70 persen dari total produksi batik. Ia juga mengatakan, walaupun batik printing Cina dengan batik printing Solo sudah memiliki pangsa pasar sendiri-sendiri tetapi nanti dapat menyerang motif-motif yang umumnya diproduksi para UKM di samping motif-motif seragam.

Sedangkan studi penelitian yang dilakukan

Tabel 1. Realisasi Ekspor Komoditi Batik dan Batik Garmen di Eks Karesidenan Surakarta Tahun 2006 - 2008

\begin{tabular}{lrrrrrr}
\hline Kabupaten/ & \multicolumn{3}{c}{ Volume (kg) } \\
Kota & \multicolumn{1}{c}{$\mathbf{2 0 0 6}$} & \multicolumn{1}{c}{$\mathbf{2 0 0 7}$} & \multicolumn{1}{c}{$\mathbf{2 0 0 8}$} & \multicolumn{1}{c}{$\mathbf{2 0 0 6}$} & \multicolumn{1}{c}{$\mathbf{2 0 0 7}$} & \multicolumn{1}{c}{$\mathbf{2 0 0 8}$} \\
\hline Surakarta & $140.649,42$ & $386.927,33$ & $401.228,73$ & $2.498 .539,51$ & $2.826 .539,63$ & $4.887 .483,85$ \\
Karanganyar & $56.743,11$ & $61.735,54$ & $60.736,36$ & $538.942,84$ & $554.647,34$ & $561.243,77$ \\
Sragen & $94.568,28$ & $92.749,21$ & $96.321,89$ & $983.435,38$ & $1.283 .396,58$ & $1.184 .748,48$ \\
Wonogiri & $46.287,76$ & $38.356,99$ & $39.518,41$ & $482.385,90$ & $392.664,23$ & $431.947,82$ \\
Sukoharjo & $68.910,44$ & $64.648,68$ & $71.247,43$ & $527.947,24$ & $594.748,35$ & $566.643,51$ \\
Klaten & $90.321,63$ & $94.993,24$ & $86.936,47$ & $836.495,54$ & $932.312,84$ & $719.640,22$ \\
Boyolali & $83.845,81$ & $86.351,32$ & $91.498,76$ & $927.280,26$ & $934.739,93$ & $968.995,27$ \\
\hline
\end{tabular}

Sumber: Disperindag Kota Surakarta 
Nazar dan Saleem (2009) menyatakan bahwa adanya model pencapaian ekspor bisa membantu perusahaan untuk meningkatkan ekspor melalui Karakteristik manajemen, kemampuan strategi pemasaran ekspor, karakteristik perusahaan yang berpengaruh positif terhadap pencapaian ekspor. Kajian Patel-D'Souza (2009) menyatakan bahwa inovasi tidak berpengaruh signifikan terhadap pencapaian ekspor.

Dari hasil beberapa kajian yang pernah dilakukan tersebut, penelitian ini mencoba memasukkan stimulus ekspor yang diharapkan dapat memperkuat pencapaian ekspor usaha batik di eks. Keresidenan Surakarta, yang dinyatakan: apakah stimulus ekspor berpengaruh signifikan terhadap perusahaan batik di Eks. Karesidenan Surakarta? dan apakah stimulus ekspor berpengaruh terhadap pencapaian ekspor perusahaan batik di Eks Karesidenan Surakarta. Sedang tujuan penelitian ini adalah membuktikan dan menganalisis: stimulus ekspor terhadap strategi ekspor yang digunakan oleh perusahaan batik di Eks. Karesidenan Surakarta. Pengaruh stimulus ekspor terhadap pencapaian ekspor perusahaan batik di Eks Karesidenan Surakarta

Hasil studi ini diharapkan akan bermanfaat bagi pemerintah, utamanya Pemerintah Kota/Kabupaten di Eks Karesidenan Surakarta dalam rangka otonomi daerah serta mengidentifikasi kelompok-kelompok pengrajin batik yang belum tersentuh kebijakan pemerintah serta mendorong dan menstimulus industri batik untuk dapat terus berkembang menjadi industri unggulan di Eks Karesidenan Surakarta.

\section{METODE PENELITIAN}

Jenis penelitian yang dipakai adalah penelitian explainatory yaitu menjelaskan pengaruh variabel stimulus ekspor terhadap strategi ekspor dan pencapaian ekspor. Tempat penelitian berada di wilayah sentra industri batik di tujuh kabupaten kota sebagaimana tercantum dalam Tabel 2. Pemilihan tempat ini berdasarkan hasil studi lapangan yang dilaksanakan bulan JuniJuli 2009. Populasi dalam penelitian ini adalah perusahaan batik yang berada di wilayah Eks Karesidenan Surakarta yang melakukan ekspor batik keluar negeri dan pada saat penelitian berlangsung masih melakukan kegiatan ekspor.

Berdasarkan gambaran target dan karakteristik populasi tersebut, maka teknik pengambilan sampel yang digunakan untuk pemilihan sampel yang representatif adalah dengan mengelompokkan ke tujuh wilayah kota/kabupaten produsen batik kedalam gugus sederhana (simple cluster sampling) dengan cara menggolongkan perusahaan-perusahaan yang mengekspor batik ke luar negeri ke dalam gugus-gugus yang disebut cluster dalam tujuh wilayah pengekspor batik. Karena masing-masing perusahaan batik yang dijadikan sampel relatif homogen karena ciri karakteristiknya hampir sama, yaitu perusahaan-perusahaan yang memproduksi dan mengekspor batik secara langsung ke luar negeri, maka pengambilan sampel pada wilayah secara judgement sampling (Sampel dipilih berdasarkan penilaian peneliti bahwa dia adalah pihak yang paling baik untuk dijadikan sampel penelitiannya). Dari total 108 perusahaan yang melakukan ekspor, 4 perusahaan menolak untuk dijadikan sampel, berdasarkan pertimbangan tersebut maka sampel yang diambil sebanyak 96 persen atau sebanyak 104 perusahaan. Hasil pengambilan sampel untuk ketujuh sub populasi kota/kabupaten ditunjukkan seperti pada Tabel 2 .

Tabel 2. Jumlah Anggota Populasi dan Sampel Perusahaan Batik yang Mengekspor Batik

\begin{tabular}{clcc}
\hline No. & $\begin{array}{l}\text { Kota/Kabu- } \\
\text { paten }\end{array}$ & $\begin{array}{l}\text { Jumlah Anggota } \\
\text { Populasi kota/ } \\
\text { Kabupaten }\end{array}$ & $\begin{array}{c}\text { Jumlah } \\
\text { sampel }\end{array}$ \\
\hline$(1)$ & $\begin{array}{c}(2) \\
(3)\end{array}$ \\
1. & Surakarta & 25 & $(4)$ \\
2. & Karanganyar & 12 & 24 \\
3. & Sragen & 19 & 12 \\
4. & Wonogiri & 9 & 8 \\
5. & Sukoharjo & 13 & 12 \\
6. & Klaten & 14 & 14 \\
7. & Boyolali & 16 & 16 \\
& Total Popu- & $\mathbf{1 0 8}$ & $\mathbf{1 0 4}$ \\
\hline
\end{tabular}

Sumber: Disperindag, Kota Surakarta 2007

Pengumpulan data dilakukan dengan penyebaran daftar pertanyaan kepada responden terpilih. Data yang dikumpulkan dari responden merupakan data kerat lintang (cross-sec- 
tion). Hasil proses pengolahan data ini digunakan untuk mengestimasi parameter dari variabel-variabel yang diteliti. Selain data cross-section sebagai data primer, sumber lain untuk pengumpulan data yang terkait dengan penelitian ini diperoleh dari beberapa instansi yang menyediakan data sekunder, untuk melengkapi data primer seperti: Dinas Perindustrian dan Perdagangan, Kadin (Kamar Dagang dan Industri, Badan Pusat Statistik serta beberapa website yang berkaitan dengan industri batik.

Skala pengukuran yang digunakan untuk mengukur item-item pertanyaan adalah skala Likert. Skala ini merupakan skala interval digunakan untuk mengukur pertanyaan yang ada dalam daftar pertanyaan tentang tingkat persetujuan atau ketidaksetujuan dari beberapa indikator yang membentuk variabel laten.

Pada desain kuesioner diuraikan berbagai indikator-indikator yang membentuk variabel laten serta item-item atau butir-butir pertanyaan yang disusun dalam bentuk daftar pertanyaan tertutup (close questionnaires). Kuesioner terbagi menjadi dua bagian, pertama merupakan pertanyaan yang menjaring data demografis responden perusahaan. Sedang kuesioner yang kedua, merupakan pertanyaan-pertanyaan yang berkaitan dengan variabel penelitian.

Stimulus selalu terkait dengan motivasi, karena motivasi dihasilkan dari suatu stimulus. Motivasi menggambarkan bagaimana perilaku yang ditimbulkan, diperkuat, didukung dan diarahkan serta dihentikan. Motivasi adalah proses yang menentukan pilihan seseorang diantara berbagai pilihan aktivitas (Fredon dikutip dari Morgen 1997). Adapun stimulus ekspor diukur dari empat indikator sebagai berikut: (1) Stimulus internal proaktif: Pemanfaatan kemampuan dan ketertarikan Manajer; (2) Stimulus internal reaktif: Pemanfaatan kapasitas produksi yang tersedia; (3) Stimulus eksternal proaktif:
Bantuan Pemerintah; (4) Stimulus eksternal reaktif: Keringanan Tarif.

Sedangkan Strategi pemasaran ekspor adalah sarana yang memungkinkan seorang perusahaan merespon kekuatan pasar untuk memenuhi tujuannya, melalui semua aspek dari bauran pemasaran, termasuk, produk, harga, promosi, distribusi, dan pemasaran internasional, faktor kunci yang mempengaruhi strategi pemasaran yang meliputi keputusan untuk standarisasi atau beradaptasi dengan kondisi pasar luar negeri (Cavusgil \& Zou, 1994). Menurut Cavusgil \& Zou (1994) dan O'Cass \& Julian (2003) variabel strategi ekspor diukur berdasarkan indikator-indikator sebagai berikut (1). Tingkat adaptasi: (a) Kemampuan adaptasi; (b) Kemampuan menanggulangi hambatan untuk adaptasi; (2). Tingkat standarisasi: (a) Kemampuan melakukan standarisasi, (b) pengalaman membantu perusahaan dalam standarisasi

Pencapaian ekspor terdefinisi sebagai hasil dari kegiatan suatu perusahaan di pasar ekspor. Menurut penelitian Nazar dan Saleem (2009) serta penelitian dari Oyeniyi (2009), indikatorindikator dalam membentuk variabel pencapaian ekspor batik adalah: (1) Perkembangan Program: (a) Kualitas hasil pekerjaan di pasar ekspor, (b) Ketepatan waktu dalam distribusi ke pasar; (2) Perkembangan Keuntungan: (a) Biaya Ekspor, (b) Keuntungan Ekspor, (c) Perkembangan Pasar Ekspor, dan (d) Peningkatan Penjualan Ekspor

Semua indikator variabel dari stimulus ekspor, strategi ekspor dan pencapaian ekspor diukur dengan persepsi dari perusahaan batik yang ada di Eks Karesidenan Surakarta yang melakukan ekspor dengan menggunakan skala likert lima tingkat, yaitu sangat tidak setuju=1, tidak setuju $=2$, netral $=3$, setuju $=4$, dan sangat setuju $=5$.

Tabel 3. Hasil Perhitungan Model Struktural

\begin{tabular}{lcccc}
\hline \multicolumn{1}{c}{ Hubungan Variabel } & C.R. & $\begin{array}{c}\text { Koefisien } \\
\text { Jalur }\end{array}$ & P & Kriteria \\
\hline Strategi_Ekspor <-- Stimulus ekspor & 4,276 & 0,121 & 0,045 & Sig. \\
Pencapaian_Ekspor <-- Stimulus ekspor & 6,557 & 0,120 & 0,014 & Sig. \\
Pencapaian_Ekspor <-- Strategi Ekspor & 2,434 & 0,098 & 0,001 & Sig. \\
\hline
\end{tabular}

Sumber: Hasil Perhitungan Data Menggunakan Amos 18 
Tabel 4. Hasil Pengujian Indikator Pembentuk Variabel Stimulus Ekspor

\begin{tabular}{lccc}
\hline \multicolumn{1}{c}{ Indikator } & $\begin{array}{c}\text { Loading } \\
\text { Factor }\end{array}$ & $\mathbf{P}$ & Mean \\
\hline Pemanfaatan kemampuan dan ketertarikan Manajer & 0,996 & Fix & 4,07 \\
Pemanfaatan kapasitas produk yang masih tersedia & 0,311 & $<0,001$ & 4.07 \\
Bantuan Pemerintah & 0,135 & $<0,001$ & 4,10 \\
Keringanan Tarif & 0,063 & 0,007 & 3,85 \\
\hline
\end{tabular}

Tabel 5. Hasil Pengujian Indikator Pembentuk Variabel Strategi Ekspor

\begin{tabular}{lccc}
\hline \multicolumn{1}{c}{ Indikator } & $\begin{array}{c}\text { Loading } \\
\text { Factor }\end{array}$ & P & Mean \\
\hline Keunikan produk & 0,260 & $<0,001$ & 4,06 \\
Adaptasi desain produk & 0,914 & Fix & 3,92 \\
Kemampuan melakukan standarisasi dan bauran & 0,208 & $<0,001$ & 3,85 \\
pemasaran & 0,375 & $<0,001$ & 4,02 \\
pengalaman internasional & & & \\
\hline
\end{tabular}

\section{Uji Validitas dan Reliabilitas}

Uji ini dilakukan untuk menganalisa konsistensi internal dari seluruh item yang digunakan dalam pengukuran variabel. Konsistensi internal akan memberikan indikasi adanya kesamaan item dalam mengukur konstruk yang tidak dapat diukur secara langsung (unobserved).

Reliabilitas skala pengukuran adalah sejauh mana suatu skala dapat memberikan hasil yang konsisten apabila pengukuran dengan skala tersebut dilakukan pengulangan (Malhotra, 1999:281). Dengan kata lain, reliabilitas adalah seberapa besar hasil pengukuran yang diperoleh melalui skala tertentu tidak terdapat kesalahan.

Untuk menjawab permasalahan dalam penelitian ini, serta menguji model yang diajukan maka teknik analisis yang digunakan adalah model persamaan struktural (structural equation modeling) yang selanjutnya disebut SEM. Sebagai salah satu teknik analisis multivariat, SEM memungkinkan dilakukannya analisis terhadap serangkaian hubungan secara bersamaan hingga memberikan efisiensi statistik (Hair et al., 1998).

\section{HASIL DAN PEMBAHASAN}

\section{Deskripsi Batik di Eks Karesidenan Surakarta}

Batik di Eks Karesidenan Surakarta ini lebih sering disebut sebagai batik pedalaman, seperti di Yogyakarta dan Surakarta. Batik di wilayah ini mayoritas memiliki pola simetris, motif besar, mengangkat tema kehidupan masyarakat darat (hutan, hasil bumi, dan agraria) serta simbol-simbol kerajaan. Pemilihan warnanya adalah nuansa alam, seperti coklat (sogan) yang menggambarkan kebersahajaan dan membumi. Hal tersebut selaras dengan kehidupan sosial, budaya, lingkungan Yogyakarta dan Surakarta sebagai lingkup kraton dengan karakter halus dan pelan (Djoemena, 1990).

Batik-batik gaya Surakarta secara umum mulai merajai ke berbagai pelosok tanah air. Diantaranya ragam hias Sawat, Slobog, Sido Mukti, Sido Luhur, Ratu Ratih, Truntum, Satrio Manah, Pamiluto. Sementara untuk motif batik dalem kraton sendiri terdapat di antaranya motif Semen Rama yang dibuat pada masa PB IV tahun 1787 sampai tahun 1816. Motif Indrabrata, Bayubrata, Agnibrata, Babon Angrem, Semen Sida Raja, Naga Raja, Semen Candra, Semen Prabu, Parang Kusuma, Wirasat dan lain-lain.

Selanjutnya dalam Wilayah Eks Karesiden- 
an Surakarta atau lebih dikenal dengan nama Subosuka Wonosraten (Surakarta, Boyolali, Sukoharjo, Karanganyar, Wonogiri dan Klaten) mencoba untuk membina para pengrajin batik dengan membentuk sentra pengarjin batik dalam wadah Usaha Mikro Kecil dan Menengah (UMKM) Subosuka Wonosraten. Wadah inilah yang membantu para pengrajin atau industri batik di wilayah eks. Karesidenan Surakarta untuk menjual (ekspor) batik ke luar negeri.

\section{Gambaran Umum Perusahaan Batik di Eks Karesidenan Surakarta}

Industri batik merupakan unsur penting dalam aktivitas ekonomi di wilayah Eks Karesidenan Surakarta. Mula-mula pembuatan batik hanya merupakan industri rumah tangga. Pembuatan batik dilaksanakan oleh putri-putri keraton sebagai pengisi waktu luang. Putri kraton melakukan pekerjaan membatik dengan cara menutup permukaan kain dengan lilin, sedang proses pewarnaan dan finishing dilakukan oleh abdi dalem. Keterampilan membatik yang dimiliki oleh putri bangsawan dan para abdi dalem kemudian melahirkan potensi ekonomi yang mengubah sifat batik dari ekspresi seni menjadi sumber ekonomi masyarakat. Terjadinya perubahan ekonomi dan meningkatnya kebutuhan akan batik yang melambung tinggi, menyebabkan industri rumah tangga ini berkembang menjadi industri yang dikelola oleh para pengusaha dan pedagang batik. Perkembangan industri batik sangat dipengaruhi oleh perubahan politik dan ekonomi. Intervensi politik dan ekonomi yang dilakukan oleh Pemerintah Belanda yang semakin intensif pada abad ke-19 telah mengakibatkan kondisi ekonomi rakyat semakin buruk. Di kalangan kaum bangsawan, kesulitan ekonomi dan besarnya pengeluaran mengakibatkan warga istana Surakarta terlibat hutang dalam jumlah sangat banyak. Peralihan dari karya seni menjadi bentuk industri mengakibatkan batik mengalami banyak perubahan dan perkembangan. Perempuan menjadi sumberdaya ekonomi yang sangat berarti dalam industri dan perdagangan batik. Setelah batik berkembang menjadi hasil industri yang diperdagangkan, batik menjadi sumber penghidupan bagi masyarakat.
Kota Solo merupakan kota terbesar dari tujuh kota eks karesidenan Surakarta, dari kota Solo inilah muncul produsen batik besar yang lebih modern, yang menghantam industri batik tulis. Awal tahun 1970, perusahaan ini menanamkan modal sebesar Rp300 juta untuk pabrik tekstil batiknya, dan hanya dalam kurun waktu dua tahun berhasil menjual 100 juta yard per tahunnya. Dampak ekspansi jenis perusahaan ini benar-benar memukul keberadaan industri batik tulis, sehingga pada akhir dekade 1970-an, pengrajin batik yang semula menyemarakkan kegiatan rumah tangga di Laweyan Surakarta dan sekitarnya dan beberapa kota lain menjadi lumpuh.

Sejarah perkembangan industri batik di Kabupaten Karanganyar mengalami perkembangan pasang surut seperti halnya di Kota Solo. Sedangkan corak batik di Kabupaten Karanganyar, mengikuti corak-corak lukisan binatang dan tanaman, lambat laun motif ini beralih pada motif abstrak yang menyerupai awan, relief candi, wayang beber, dan sebagainya. Selanjutnya melalui penggabungan corak lukisan dengan seni dekorasi pakaian, muncul seni batik tulis seperti yang kita kenal sekarang ini. Sentra produksi batik di Kabupaten Karanganyar dijumpai di Kecamatan Matesih, Jaten, Gondangrejo dan Karanganyar. Jumlah produksi batik sebanyak 25.028 kodi/tahun. Dari sisi permintaan, peluang usaha di bidang industri batik masih terbuka dan sangat menguntungkan.

Batik merupakan salah satu kerajinan tradisional yang menjadi produk unggulan Kabupaten Sragen. Kabupaten Sragen hingga kini memiliki sebanyak 4.542 unit usaha batik tulis dengan jumlah perajin batik 12.353 orang, 44 fasilitas show room dan 2 art gallery yang sebagian besar tersebar di Desa Kliwonan, Pilang dan Sidodadi yang terletak di Kecamatan Masaran. Khusus untuk Kecamatan Masaran ada 2.567 unit usaha batik yang mampu menyerap tenaga kerja 7.233 orang. Perajin batik Sragen setiap bulan mampu memproduksi sebanyak 1.201.500 potong bahan batik untuk konsumsi pasar domestik seperti Pulau Jawa dan luar Pulau Jawa. Sebagian pembatik lainnya berdomisili di desa Gedongan, Jabung Kecamatan Plupuh dan Kecamatan Kalijambe. Adapun in- 
dustri besar batik di Sragen mencapai 82 unit dengan kapasitas produksi mencapai lebih dari $69.000 \mathrm{kodi} /$ tahun. Tenaga kerja yang terserap tiap tahun sebanyak 2.079 orang dengan nilai produksi lebih dari Rp22,23 miliar per bulan. Produksi batik Sragen meliputi batik tulis, cap, dan printing dengan berbagai ragam produk seperti Sarimbit, Sarung Selendang, jarik, kemeja, dan blus. Industri batik membuka peluang besar untuk penanaman modal dalam hal pengadaan bahan baku, pengembangan produksi, pelatihan dan keterampilan, serta promosi dan pemasaran.

Potensi industri batik di daerah Kabupaten Wonogiri terletak di daerah Tirtomoyo. Daerah ini merupakan daerah Kabupaten Wonogiri yang cukup subur dan memiliki industri batik tulis dan industri genteng di sekitar Sungai Wiroko. Dua industri tersebut, mampu mengurangi angka pengangguran. Untuk industri rumah tangga, batik tulis Wonogiren menyerap tenaga kerja mencapai 250 orang, sedangkan industri genteng sekitar 200-an tenaga. Industri batik tulis, di daerah Ngarjosari hingga saat ini masih dilestarikan karena turun temurun.

Industri batik di Kabupaten Sukoharjo berada di desa Kertonatan, yang merupakan satu dari 10 desa di Kecamatan Kartasura, Sukoharjo, yang kini tengah giat membangun dan mengembangkan sektor industri kecil seperti, konveksi dan perdagangan. Konveksi batik, menjadi andalan Desa Kertonatan. Menurut salah seorang pedagang batik sekaligus pengusaha konveksi batik di Desa Kertonatan, usaha konveksi batik di Kertonatan sudah berkembang sejak puluhan tahun lalu ketika Pasar Klewer, Solo mulai berdiri. Pada awalnya di duksi batik di Klaten terdapat di desa Sekarsuli Kecamatan Klaten Utara, dan desa Tempursari Kecamatan Ngawen.

Untuk perkembangan industri batik di Kabupaten Boyolali banyak terdapat perindustrian yang bergerak dalam bidang textil, antara lain PT. Sariwarna, PT. Safaritex, PT. Bupatex. Industri-industri ini sebagai penyangga dan pemasok utama kain-kain yang akan dijadikan batik di wilayah Jawa Tengah, khususnya Eks Karesidenan Surakarta.

\section{Stimulus Ekspor}

Untuk dapat melihat nilai stimulus ekspor ada empat indikator yang digunakan yaitu stimulus internal proaktif (pemanfaatan kemampuan dan preferensi manajer untuk ekspor) stimulus internal reaktif (pemanfaatan kapasitas produksi yang belum digunakan, dan stimulus eksternal proaktif (bantuan Pemerintah) serta stimulus eksternal reaktif berupa keringanan tarif.

\section{Pencapaian Ekspor}

Ada 6 indikator untuk menggambarkan 3 hal penting dalam pencapaian ekspor yaitu perkembangan program yang meliputi kualitas hasil pekerjaan di pasar ekspor serta ketepatan waktu dalam distribusi ke pasar dan perkembangan keuntungan yang meliputi Biaya Ekspor, Keuntungan Ekspor, Perkembangan Pasar Ekspor dan Peningkatan Penjualan ekspor. Persepsi responden mengenai variabel karakteristik lingkungan dapat dilihat pada Tabel 3.

\section{Hasil Perhitungan Model Struktural}


struktural (SEM) menunjukkan bahwa model ini sesuai dengan data atau fit dengan data dalam penelitian. Dari hasil perbandingan kriteria goodness-of-fit dengan hasil perhitungan persamaan struktural menunjukkan bahwa significance probability, CMIN/DF=1,762, GFI= 0,955, AGFI $=0,932$, TLI $=0,991, \mathrm{CFI}=0,982$ dan RMSEA $=0,025$ terpenuhi, kriteria chi square hanya memenuhi syarat secara marginal, namun hal ini masih dapat diterima. Hasil perhitungan ini dengan signifikansi perbedaan chi square $=$ 94,999 dan probabilitas sebesar 0,083 membuktikan bahwa tidak terdapat perbedaan antara kedua kovarians yang diuji dan karena itu mengkonfirmasi kesesuaian model.

\section{Strategi Ekspor}

Berdasarkan Tabel 5 diketahui bahwa keempat indikator tersebut signifikan membentuk variabel Strategi Ekspor dan diperoleh bahwa indikator kedua yaitu adaptasi desain produk merupakan indikator dengan loading factor tertinggi untuk strategi ekspor dengan nilai sebesar 0,914. Berarti strategi ekspor banyak ditentukan oleh kemampuan desain produk perusahaan yang mampu menyesuaikan keinginan pasar luar negeri.

\section{Pencapaian Ekspor}

Berdasarkan Tabel 6 dapat diketahui bahwa
0,996. Berarti stimulus ekspor lebih banyak ditentukan kemampuan pemanfatan kapasitas produksi yang ada. positif $(0,121)$ berarti hubungan kedua variabel ini adalah positif, artinya semakin tinggi stimulus ekspor, maka semakin baik penentuan strategi ekspor.

Tabel 6. Hasil Pengujian Indikator Pembentuk Variabel Pencapaian Ekspor

\begin{tabular}{lccc}
\hline \multicolumn{1}{c}{ Indikator } & Loading Factor & P & Mean \\
\hline Kualitas produk di pasar ekspor & 0,988 & Fix & 4.13 \\
Ketepatan waktu dalam distribusi ke pasar & 0,032 & 0,002 & 4,06 \\
Biaya Ekspor & 0,139 & $<0,001$ & 3,92 \\
Keuntungan Ekspor & 0,101 & 0,009 & 3,85 \\
Perkembangan Pasar Ekspor & 0,100 & 0,007 & 4,02 \\
Peningkatan Penjualan ekspor & 0,928 & $<0,001$ & 4,13 \\
\hline
\end{tabular}


Hipotesis 2: Stimulus ekspor berpengaruh signifikan terhadap pencapaian ekspor perusahaan batik di Karesidenan Surakarta. Pada hipotesis ketiga stimulus ekspor. Berdasarkan indikatorindikatornya menunjukkan hasil signifikan dengan nilai C.R. $=4,306$ atau C.R. $\geq \pm 2,00$ dengan taraf signifikansi sebesar $0,014(<0,05)$, sehingga hipotesis ini diterima. Mengingat koefisien bertanda positif $(0,120)$ berarti hubungan kedua variabel ini adalah positif, artinya semakin baik stimulus ekspor dipersepsikan oleh nal, bantuan mengakses dana maupun pelatihan serta adanya kebijakan dari negara pengimpor yang memberi peluang eksportir negara lain akan memudahkan perusahaan melakukan penyesuaian serta standarisasi yang lebih baik.

\section{Pengaruh Variabel Stimulus Ekspor terhadap Variabel Pencapaian Ekspor}

Pengaruh stimulus ekspor secara langsung berpengaruh terhadap pencapaian ekspor melalui ctratosi okennr Mari cici olkctornal hal ini co-

\section{Pengaruh Variabel Stimulus Ekspor terhadap Strategi Ekspor}

Variabel stimulus ekspor memiliki pengaruh signifikan terhadap strategi ekspor. Artinya semakin membaik stimulus ekspor dari sudut pandang eksportir, menstimuli perusahaan ekspor batik untuk mencari peluang dan mengembangkan strategi yang sesuai dengan kondisi pasar internasional.

Stimulus ekspor dapat berasal dari lingkungan internal, maupun eksternal perusahaan pengekspor. Stimulus dari lingkungan internal dapat berupa keinginan kuat dari pimpinan (pemilik/manajer) perusahaan untuk memanfaatkan seluruh sumber daya yang dimiliki perusahaan untuk keperluan pasar ekspor (proaktif) supaya tumbuh lebih besar dan keuntungan menjadi lebih besar yang diperoleh dari kegiatan di pasar ekspor. Selain itu stimulus dari lingkungan eksternal baik dari bantuan pemerintah berupa informasi pasar internasio- tersedia semuanya mendorong peningkatan pencapaian ekspor.

Dalam kenyataan stimulus ekspor dinilai baik oleh responden $(4,02)$. Stimulus ekspor dari internal maupun eksternal, yang paling penting menurut responden adalah pemanfaatan kemampuan dan ketertarikan manajer (loading tertinggi 0,996) dan ini juga sudah dilakukan dengan baik (nilai 4,07). Batik adalah produk yang merupakan karya seni dan budaya yang dimliki oleh Indonesia, maka pemerintah sebagai pihak yang membuat kebijakan, dapat memberikan stimulus untuk dapat membantu perusahaan-perusahaan batik yang ada di indonesia agar supaya pencapaian ekspor batik mereka dapat meningkat. Demikian pula perusahaan juga harus dapat memanfaatkan sumberdaya mereka sendiri untuk peningkatan capaian ekspor mereka.

\section{Pengaruh Variabel Strategi Ekspor terhadap Variabel Pencapaian Ekspor}

Secara operasional, pengertian strategi ekspor 
merupakan rata-rata suatu perusahaan merespon kekuatan pasar secara obyektif melalui semua aspek bauran pemasaran termasuk produk, harga, promosi dan distribusi. Dari pemasaran internasional faktor kunci yang merupakan faktor penentu dalam mempengaruhi strategi yaitu standarisasi dan kemampuan melakukan adaptasi sesuai kondisi pasar asing (Cavusgil dan Zou, 1994; Douglas dan Craig, 1987).

Hasil studi ini menunjukkan bahwa pengaruh strategi adaptasi atau standarisasi secara signifakan berdampak pada kinerja pencapaian ekspor. Artinya pengusaha ekspor batik dapat meningkatkan pencapaian ekspor dengan cara adaptasi maupun standarisasi. Perusahaan yang lebih mempunyai kekuatan atau keunikan produknya, pengalaman dalam mengekspor, punya komitmen lebih besar pada peningkatan sumber daya untuk ekspor, akan lebih mudah melakukan strategi adaptasi untuk ekspor.

Dalam kenyataan, strategi ekspor dinilai baik oleh responden (nilai 3,96). Di antara indikator strategi ekspor, yang paling penting menurut responden adalah kemampuan adaptasi desain produk (loading tertinggi 0,914) dan ini juga sudah dilakukan dengan baik (nilai 3,92 ). Mengingat batik adalah produk fashion, di mana selera konsumen cepat berubah, memang dituntut peningkatan kreativitas untuk mendesain batik dengan model-model baru baik corak maupun warna sesuai dengan keinginan masing-masing negara tujuan ekspor. Bukan hanya kemampuan adaptasi tetapi kecepatan beradaptasi juga sangat diperlukan (Drucker, 1985).

Bila stimulus ekspor proaktif, reaktif, internal maupun eksternal semakin baik, pada periode selanjutnya akan membantu perusahaan untuk menentukan strategi adaptasi dan atau standarisasi yang lebih tepat dan akhirnya berdampak pada pencapaian ekspor yang lebih baik. Demikian juga semakin kuat sumber daya internal yang mendukung kegiatan ekspor, adanya bantuan pemerintah baik dalam bentuk dana maupun informasi pasar luar negeri yang lebih lengkap, akan membantu membuat keputusan strategi adaptasi yang lebih sesuai, misalnya membatik dengan corak, warna, mutu, harga sesuai dengan keinginan pasar yang meng- hasilkan peningkatan jumlah ekspor.

Penelitian ini menggunakan populasi dan sampel dari perusahaan eksportir Batik di daerah Eks Karesidenen Surakarta saja. Maka jika hasil penelitian ini digunakan produsen Batik di luar wilayah Eks Karesidenan Surakarta, mungkin akan memberikan hasil berbeda karena adanya perbedaan karakteristik lingkungan dan budaya.

\section{SIMPULAN}

Secara umum stimulus ekspor, dan strategi ekspor mempunyai peran dalam meningkatkan pencapaian ekspor batik di eks. keresidenan Surakarta. Berdasarkan hasil penelitian yang telah dilakukan dapat disimpulkan secara khusus beberapa hal penting sebagai berikut:

Meningkatnya Stimulus ekspor akan semakin meningkatkan efektivitas strategi ekspor yang dilakukan perusahaan eksportir batik untuk menghadapi pasar internasional. Stimulus ekspor yang meningkat juga akan meningkatkan pencapaian ekspor dari perusahaan eksportir batik, sehingga memberikan arti adanya stimulus yang diberikan pemerintah berkaitan ekspor batik di eks. keresidenan Surakarta akan dapat memotivasi perusahaan eksportir batik untuk lebih meningkatkan ekspor batiknya. Dari sisi internal pengusaha batik dapat meningkatkan pemanfaatan kemampuan dan ketertarikan yang dimiliki oleh seorang manajer serta pemanfaatan kapasitas produksi yang tersedia untuk meningkatkan stimulus ekspor. Sedangkan dari sisi eksternal pemerintah negara asal dapat meningkatkan bantuan fasilitas pendanaan serta memberikan keringanan tarif dan stimulus.

Strategi ekspor yang semakin tepat dan intensif digunakan oleh perusahaan eksportir batik akan meningkatkan pencapaian ekspornya. Strategi ekspor ditentukan oleh bagaimana kemampuaan adaptasi dari perusahaan dan juga bagaimana menanggulangi hambatan untuk adaptasi agar dapat memberikan strategi ekspor yang efektif. Dengan memiliki strategi ekspor yang tepat dan efektif maka perusahaan batik tersebut akan dapat meningkatkan ekspor batik mereka 
Secara keseluruhan dengan meningkatnya globalisasi dan meningkatnya ancaman pengusaha batik dari negara lain, pasar ekspor menjadi pilihan penting bagi perusahaan batik. Oleh karena itu baik secara teoritik maupun praktis adalah sangat penting untuk meneliti keberhasilan pencapaian ekspor yang terkait dengan persoalan-persoalan: stimulus ekspor, strategi adaptasi dan standarisasi ekspor. Untuk industri batik di daerah penelitian ini, apabila ekspotir batik ingin berhasil dalam pasar ekspor, diperlukan kemampuan dan kecepatan beradaptasi sesuai dengan kondisi pasar tujuan. Kemampuan strategi beradaptasi yang lebih baik, dapat dilakukan bila didukung oleh internal dan eksternal perusahaan, khususnya dukungan dari pemerintah setempat ke arah orientasi ekspor.

Ucapan Terima Kasih. Peneliti mengucapkan terima kasih kepada Prof. Djumilah Zain, Prof Candra Fajri, Prof Armanu, Prof Idrus, Prof Surachman, Dr. Minarti, Prof Tulus dan Prof C. Dwiatmaja, yang telah banyak memberikan koreksi serta masukan-masukan penting dalam tulisan ini. Tiada lupa ucapan terima kasih kepada Mirat Sidharta dan Didit Purnomo, selaku reviewer dan editing perbaikan naskah ini

\section{DAFTAR PUSTAKA}

Badan Pusat Statistik (BPS). 2009. Ekspor Non Migas Utama Menurut Komoditi (Sitc 2 Digit). Jakarta: Badan Pusat Statistik

Cavusgil, S.T., \& Zou, S. 1994. Marketing Strategy-Performance Relationship: Investigation of The Empirical Link In Export Market Ventures. Journal of Marketing, 58, 1-21.

Disperindag. 2007. Rencana Pengembangan Industri di Surakarta. Surakarta: Bagian Penerbitan Disperundag Kota Surakarta.

Djoemena, Nian S. 1986. Ungkapan Sehelai Batik. Jakarta: Djambatan.

Djoemena, Nian S. 1990. Batik dan Mitra. Jakarta: Djambatan.

Douglas, Susan P. And Wind, Yoram. 1987. The Myth Of Globalization. The Columbia Jour- nal of World Business, XXXII (4), Winter, 19-29.

Drucker, P. 1985. Innovation and Entrepreneurship, Practice and Principles. New York Harper \& Row.

Ferdinand, Augusty. 2002. Structural Equation Modelling. Semarang: Badan Penerbit Universitas Diponegoro.

Grier, Kevin B. Aaron D. Smallwood, 2006. Uncertainty and Export Performance: Evidence from 18 Countries, JEL Classifications: F40, C32, 1-29.

Ha, Soo Jung and Swales, J. Kim. 2010. The Export Base Model with a Supply-side Stimulus to The Export Sector", Strathclyde Discussion Papers in Economics, Departemen of Economics University of Strathclyde Glasgow.

Hamzuri. 1981. Batik Klasik. Jakarta: Penerbit Djambatan.

Hasanul Haque and 'Mahbubur Rahman. 2002. Textile and Apparel Export from Bangladesh: Measure of Competitiveness, Pakistan Journal of Applied Sciences 2 (9): 882-888

Hiep, N. and H. Ohta, 2008. Superiority of Exporters and the Causality between Exporting and Firm Characteristics in Vietnam. RIEB Discussion Paper.

Nazar, Muhammad Suhail and Saleem, Hassan Mujtaba Nawaz, 2009. Firm-Level Determinants of Export Performance International Business \& Economics Research Journal, Volume 8, Number 2, 1-8.

O'Cass, A. 2001. Consumer Self-Monitoring, Materialism and Involvement in fashion clothing, Australian Marketing Journal, Vol. 9, No. 1, pp. 46-60.

Oyeniyi, Ototayo. 2009. Effect of Marketing Strategy on Export Performance: Evidence from Nigerian Export Companies Effect of Marketing Strategy on Export Performance Evidence from Nigerian Export Companies, Economic and Administrative Series University of Bucharest, Nr. 3, pp 249-261. 
Riyanto, Didik. 1995. Proses Batik Tulis, Batik Cap dan Batik Printing. Solo: CV. Aneka Solo.

Riyanto, dkk. 1997. Katalog Batik Indonesia. Yogyakarta: Balai Besar Penelitian dan Pengembangan Industri Kerajinan dan Batik.

Santosa, Doellah. 2002. Batik: The Impact of Time and Environment. Surakarta: Danar Hadi.

Soebagyo, Daryono dan M. Wahyudi. 2008. Analisis Kompetensi Unggulan Daerah pada Produksi Batik Tulis dan Cap di Dati II Kota Surakarta, Jurnal Ekonomi
Pembangunan FE UMS, Vol.9 No.2 Desember 2008 BPPE Fakultas Ekonomi UMS

Soebagyo, Daryono. 2007. Pengembangan UKM yang Berdasarkan Kompetensi di Kota Surakarta, Hasil Riset Diseminasi Pengkajian Kompetensi Inti Daerah. Penelitian di Publikasikan oleh Deperindag RI.

Zou, S., Taylor, C.R. and Osland, G.E. 1998. The EXPERF Scale: a cross-national Generalized Export Performance Measure, Journal of International Marketing, Vol. 6 No. 3, pp. 37-58. 